\title{
Microorganisms Producing Biosurfactant Selection and Characterization of New Discovered Bioemulsifier that will be Used to Create Ecological Heating Production Technology
}

\author{
G. Žèkaitė ${ }^{1}$, V. Jaška ${ }^{1}$, K. Poška ${ }^{1}$, M. Andrulyté2, S. Grigiškis ${ }^{1,2}$ \\ 1 - JSC „Biocentras“, V. Gračiūno st. 10, LT 02241 Vilnius, Lithuania; + (370) 526613 13, \\ fax: +(370) 526024 54, e-mail; biocentras@biocentras.lt \\ 2 - Vilnius Gediminas Technical University, Saulètekio st. 11, LT 10223 Vilnius, Lithuania
}

\begin{abstract}
The chemical synthesis of surface active compounds is economically inefficient. It requires much energy expense, raw materials and harmful reagents. Biological biosynthesis of surface active substances happens in milder conditions without the use of dangerous chemical reagents. The main goal of this work was to select a microorganism strain capable of producing a bioemulsifier with an ability to create a stable water / fuel-oil emulsion that could be used to design a new ecological heating technology. To this end, 3 microorganism strains displaying a high emulsification activity were used. The new discovered surface active substance (SAS) was investigated with different methods (hydrocarbon overlay agar method, emulsification activity determination, microscopic observation). The production of bioemulsifier (BE) was studied by using soluble and insoluble carbon sources. It was found that Arthrobacter sp. Pr82 is the best bioemulsifier producer. Oleic acid was ascertained as the best carbon source for the production of discovered $\mathrm{BE}$.
\end{abstract}

Keywords - bioemulsifier, microorganism selection, water-oil emulsion, carbon sources

\section{INTRODUCTION}

The decreasing prospects of oil resources and continuous emissions from gas due to fossil fuel consumption have raised keen attention as urgent problems around the world. As one of the different solutions to these problems, emulsion fuel technology has received close attention, because it may provide better combustion efficiency and would contribute to a reduction in emissions, such as $\mathrm{NO}_{\mathrm{x}}$ or particulate matter (PM). There are also great expectations that it would lead to a reduction in fossil fuel consumption and carbon dioxide emissions on a global level and eventually provide a final solution to environmental problems, such as effluent gas.

Emulsion fuels refer to the emulsified mixture of petroleum-based fossil fuels, including gasoline, light oil, heavy oil, kerosene and waste oil, and water. In emulsion fuels, a mechanism which improves the combustion efficiency of the emulsified fossil fuel by virtue of the emulsified water is assumed to work.

Unfortunately, water-oil emulsions are not stable enough and are usually created before use, as they cannot be transported or stored for long periods of time. In order to stabilize them, surfactants with emulsifying qualities, i.e., emulsifier, need to be used. Synthetic emulsifiers are expensive and their synthesis requires not a small amount of energy expense and pure reagents. These chemically synthesized surfactants are mainly petroleum based and are usually non-biodegradable thus remain toxic to the environment they find themselves [1]. The use of synthetic emulsifiers for fuel emulsions increases its price twice; additionally there might be environmentally undesirable elements within the composition of the synthetic emulsifier [2].

As an alternative, bioemulsifiers - surface active substances, gained through biological methods and produced by bacteria and yeast strains Arthrobacter, Bacillus, Pseudomonas, Acinetobacter, Rhodococcus, Sphingomonas, Thiobacilus thiooxidans, Serratia marcescens, Agrobacterium, P.fluorescens, Debaryomyces polmorphus, P.aeruginosa, Clavibacter, C.tropicalis, Yarrowia, Candida, Torulopis, Pseudozyma, Saccaromyces [3-9], can be used. Bioemulsifiers are categorized mainly by their chemical composition and microbial origin. BSAS secreted by different microorganisms are composed of lipids, phospholipids, polysaccharides, proteins and other biological macromolecules; they contain various functional groups including carboxyl, amino and phosphate groups [10-14].

Biological surface active substances commonly have the advantages of biodegradability, low toxicity, selectivity, and biocompatibility over chemically synthesized surfactants, as well as being effective at the extreme ranges of $\mathrm{pH}$, temperature, and salinity [15]. Bioemulsifiers easily degrade and do not pollute environment [16]. Biosurfactants can be produced 


\section{Žèkaitė G., Jaška V., Poška K., Andrulytė M., Grigiškis S. MICROORGANISMS PRODUCING BIOSURFACTANT SELECTION AND CHARACTERIZATION OF NEW DISCOVERED BIOEMULSIFIER THAT WILL BE USED TO CREATE ECOLOGICAL HEATING PRODUCTION TECHNOLOGY}

from very cheap raw materials which are available in large quantities.

By comparing the properties of the acquired bioemulsifier with those of the synthetic emulsifier used in fuel emulsions, it is possible to choose the most suitable BE secreted by microorganisms. By optimizing the growth conditions, the maximal yield of bioemulsifier can be gained.

The aim of this study is to assess bacterial strain able to produce bioemulsifier which could stabilize water/fuel-oil emulsion, and to select carbon source in order to get the highest emulsification activity.

\section{MATERIALS AND METHODS}

\section{Microorganisms}

Arthrobacter sp. N3, Arthrobacter sp. Pr82 and Azotobacter vinelandii 21 bacteria strains producing surface active substances obtained from the culture collection of JSC "Biocentras" were used for investigation. The selected bacterial isolates were preserved and kept under refrigerated conditions ($70{ }^{\circ} \mathrm{C}$ )

\section{Chemicals}

All chemicals used for media preparation were obtained from the following companies: Oxoid (Basingstoke, United Kingdom), Sigma - Aldrich Chemie (Sternheim, Germany), Fluka (Sternheim, Germany), Merck (Darmstadt, Germany), Roth (Karlsruhe, Germany), Eurochemikals (Bratislava, Slovakia), Penta (Prague, Czech Republic), (LachNer, Czech Republic). Fuel-oil and crude oil were obtained from oil refinery Public Company ORLEN Lietuva (Lithuania).

\section{Inoculum preparation}

Nutrient broth (Oxoid, United Kingdom) was used for preparation of the inoculum. $0.1 \mathrm{ml}$ of bacterial strain suspension from the stock culture was inoculated into $50 \mathrm{ml}$ nutrient broth in Erlenmeyer flask. The inoculated $250 \mathrm{ml}$ flasks were incubated at $30{ }^{\circ} \mathrm{C}$ in rotary shaker (Innova 43 , New Brunswick Scientific Co. Inc, USA) for $5 \mathrm{~h}$ at $200 \mathrm{rpm}$. Inoculum was used at the $5 \%(\mathrm{v} / \mathrm{v})$ level in the all experiments with submerged cultures.

\section{Culture media and cultivation conditions}

For bioemulsifier selection, bacterial strains were cultivated in a mineral medium with the following composition $(\mathrm{g} / \mathrm{l}): \mathrm{NH}_{4} \mathrm{NO}_{3}-2.5, \mathrm{Na}_{2} \mathrm{HPO}_{4} \times 2 \mathrm{H}_{2} \mathrm{O}-$ $1, \mathrm{MgSO}_{4} \times 7 \mathrm{H}_{2} \mathrm{O}-0.5, \mathrm{Fe}\left(\mathrm{SO}_{4}\right)_{2} \times 5 \mathrm{H}_{2} \mathrm{O}-0.01$, $\mathrm{CO}\left(\mathrm{NO}_{3}\right)_{2} \times 6 \mathrm{H}_{2} \mathrm{O}-0.005, \mathrm{CaCl}_{2} \times 2 \mathrm{H}_{2} \mathrm{O}-0.001$, $\mathrm{KH}_{2} \mathrm{PO}_{4}-0.0005, \quad \mathrm{MnSO}_{4} \times 2 \mathrm{H}_{2} \mathrm{O}-0.0001$, $\left(\mathrm{NH}_{4}\right)_{6} \mathrm{Mo}_{7} \mathrm{O}_{24} \times 4 \mathrm{H}_{2} \mathrm{O}-0.0001$, yeast extract -0.1 . The carbon source was octadecane $1 \%(\mathrm{w} / \mathrm{v})$ and the final $\mathrm{pH}$ of medium was $7.2 \pm 0.2$. LB medium consisted of peptone -10 , yeast extract -5 and $\mathrm{NaCl}$ - $10 \mathrm{~g} / \mathrm{l}$. The carbon source was octadecane $1 \%(\mathrm{w} / \mathrm{v})$ and the final $\mathrm{pH}$ of medium was 7.2 \pm 0.2 . Cultivations were performed in $250 \mathrm{ml}$ Erlenmeyer flasks containing $40 \mathrm{ml}$ of medium at $30^{\circ} \mathrm{C}$ in the rotary shaker at $200 \mathrm{rpm}$ for $48 \mathrm{~h}$.

The influence of carbon source on the emulsification activity was investigated in the same mineral and LB media. The carbon sources used were oleic acid $(1 \% \mathrm{w} / \mathrm{v})$, dodecane $(1 \% \mathrm{w} / \mathrm{v})$, olive and sunflower oil $(1 \% \mathrm{w} / \mathrm{v})$ (local commercial production), glucose $(10 \mathrm{~g} / \mathrm{l})$, starch $(10 \mathrm{~g} / \mathrm{l})$, sodium acetate $(10 \mathrm{~g} / \mathrm{l})$, and glycerol $(1 \% \mathrm{w} / \mathrm{v})$. Cultivations were performed in $250 \mathrm{ml}$ Erlenmeyer flasks containing $40 \mathrm{ml}$ of medium at $30^{\circ} \mathrm{C}$ in the rotary shaker at $200 \mathrm{rpm}$ for $24 \mathrm{~h}$.

\section{Hydrocarbon overlay agar (HOA) method}

Hydrocarbon overlay agar method was performed with slight modifications [17]. Nutrient agar (Oxoid, UK) plates were coated with $40 \mu \mathrm{L}$ of crude oil. Pure bacterial isolates were streaked on to the coated plates and incubated for 48 hours at $30^{\circ} \mathrm{C}$. A streak surrounded by emulsified halos indicates biosurfactant producers.

\section{Emulsification measurement}

Emulsifier activity was measured by calculating EI according to the slightly modified method of Cooper and Goldenberg (1987) [18]. $6 \mathrm{ml}$ of kerosene were added to $4 \mathrm{ml}$ of $25 \%$ suspension of culture liquid in $0.1 \mathrm{M} \mathrm{Na}_{2} \mathrm{CO}_{3}$, and homogenized with T18 UltraTurrax homogenizer. The mixture was allowed to stand in room temperature for 24 hours prior to measurement. Emulsification index (EI) was calculated by measuring the height of the emulsion layer (a), dividing it by the total height (b) and multiplying by $100(E I=a / b \times 100)$.

\section{Preparation and microscopy of the water/fuel-oil emulsion}

Water $(30 \%)$ /fuel-oil emulsion $(20 \mathrm{~g})$ has been created using homogenizer (T18 Ultra-Turrax, IkaWerke GmbH \& Co. KG, Germany). Emulsion agitation was performed at $60{ }^{\circ} \mathrm{C}$, introducing small amounts of bioemulsifier and water into fuel-oil (fueloil + BE + water). A sample smear was taken with a piece of wire, jabbing it to the bottom after 5 days incubation at $60{ }^{\circ} \mathrm{C}$. The stuck-on emulsion was carried over to the microscope slide and covered with a cover slip. Observation and taking of photos were carried out under the magnification of $\mathrm{x} 1000$.

\section{RESULTS AND DISCUSSION}

\section{Bioemulsifier selection}

Bioemulsifiers are a very convenient alternative to chemical surfactants due to displaying little to no toxicity, high temperature stability and activity at extreme ranges of salinity and $\mathrm{pH}$. In addition, they can be modified by genetically engineering the microorganism producing it, employing biological and biochemical techniques $[19,20]$.

In this study, the best bioemulsifier was chosen from among the three species of bacteria: 


\section{Žèkaitė G., Jaška V., Poška K., Andrulytė M., Grigiškis S. MICROORGANISMS PRODUCING BIOSURFACTANT SELECTION AND CHARACTERIZATION OF NEW DISCOVERED BIOEMULSIFIER THAT WILL BE USED TO CREATE ECOLOGICAL HEATING PRODUCTION TECHNOLOGY}

Arthrobacter sp. N3, Pr82 and Azotobacter vinelandii 21. The selection was performed using hydrocarbon overlay agar (HOA) method and analyzing emulsion activity.

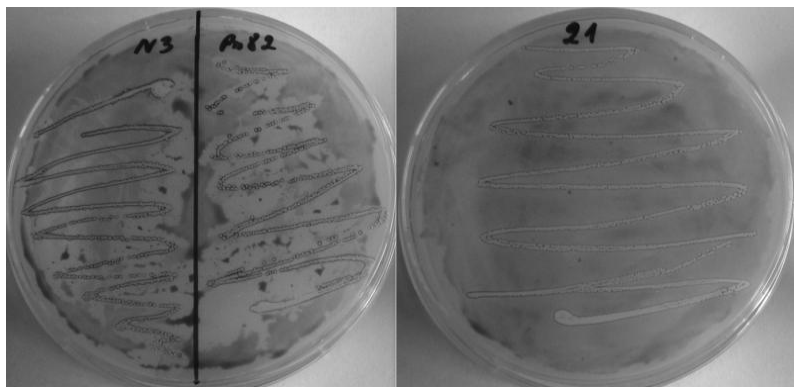

Fig. 1. Biosurfactant production by bacterial strains

During the assessment of bacteria strains using HAO method, pure bacterial culture was streaked onto the Petri dishes covered with crude oil and they were incubated for two days at a temperature of $30^{\circ} \mathrm{C}$. As shown in Fig. 1, Arthrobacter sp. N3 and Pr82 streaks were surrounded by emulsified halos, however Azotobacter vinelandii 21 didn't show any activity after two days of incubation. This method is only qualitative and colonies surrounded by emulsified halos are the direct indication of SAS producers, however it is unreliable to detect potential $\mathrm{BS} / \mathrm{BE}$ producer using a single method.

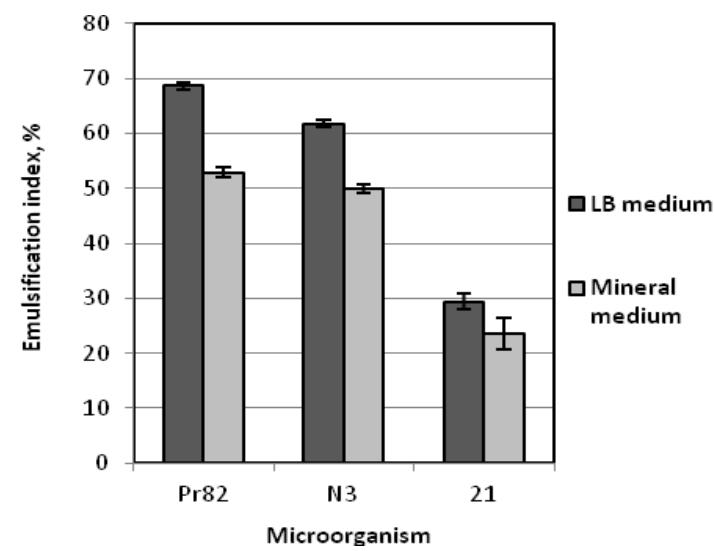

Fig. 2. Emulsification activity, using octadecane as a substrate

The bioemulsifier production may also be detected using emulsification measurement; this method was applied for the selection of bacterial strains. The results of the selection are presented in Fig. 2. The greatest emulsification activity was shown by Arthrobacter sp. Pr82 bacterial strain; in LB medium EI was 68.6 and in mineral medium - $52.9 \%$. Arthrobacter sp. N3 bacterial strain also displayed big activity - EI was $61.8 \%$ in LB medium and $50.0 \%$ in mineral medium. The emulsification index of Azotobacter vinelandii 21 was lower than $30 \%$ in LB and mineral media. Seeking to verify the stability of emulsion, the samples were kept in the temperature of $40^{\circ} \mathrm{C}$ for 5 days. After 5 days emulsion layer was measured and EI calculated. The most noticeable drop of EI has been noticed with Arthrobacter sp. N3 (30 $\%)$ and Azotobacter vinelandii 21 (32\%). Emulsion containing Arthrobacter sp. Pr82 remained the most stable, with the drop of only $11 \%$.

In order to research an influence the Arthrobacter $s p$. Pr82 BE has on water / fuel-oil emulsion stability, the emulsion agitation and microscopic observation was performed.

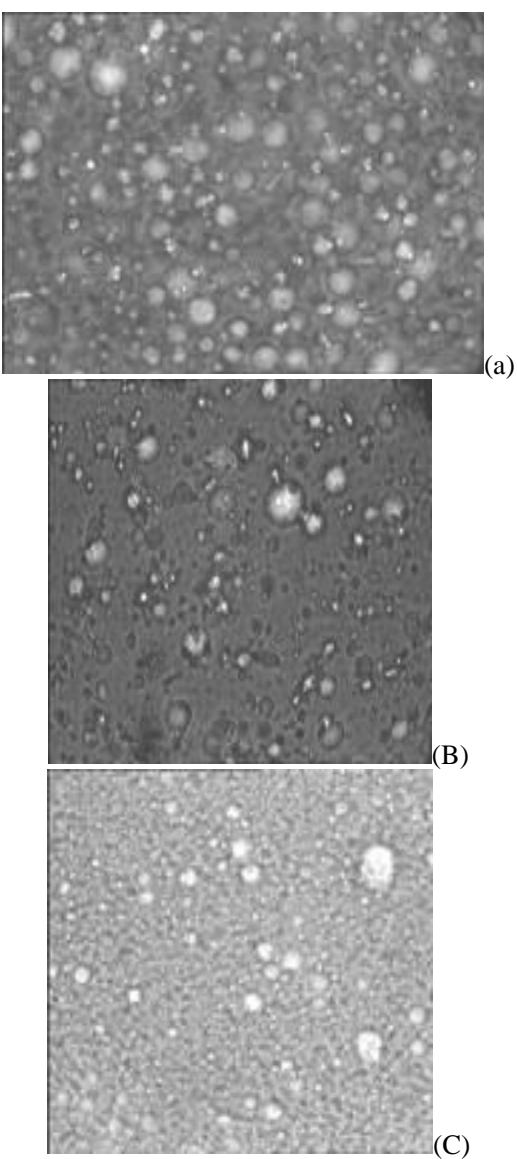

Fig. 3. $\times 1000$ magnification of water in fuel-oil emulsion

The results are shown in Fig. 3. (A - emulsion with BE from Arthrobacter sp. Pr82; B - emulsion with BE from Arthrobacter sp. N3 and C - emulsion with BE from Azotobacter vinelandii 21). The greatest emulsification illustration obtained with Arthrobacter sp. Pr82, second - with N3 and with Azotobacter vinelandii 21 visible only noises. All above discussed assays have confirmed that the greatest BE producer is Arthrobacter sp. Pr82 bacterial strain.

\section{Influence of carbon source}

A number of attempts have been made to increase bioemulsifier production by manipulating medium composition. The choice of a suitable carbon sources has a huge influence on the production of surface active substances; however its importance is organism dependent. Microorganisms can grow on various substrates, but they do not necessarily produce BSAS. The carbon source may come from raw materials, hydrocarbons, carbohydrates, lipids or from their 


\section{Žèkaitė G., Jaška V., Poška K., Andrulytė M., Grigiškis S. MICROORGANISMS PRODUCING BIOSURFACTANT SELECTION AND CHARACTERIZATION OF NEW DISCOVERED BIOEMULSIFIER THAT WILL BE USED TO CREATE ECOLOGICAL HEATING PRODUCTION TECHNOLOGY}

combinations [20, 21, 22]. BS/BE are gained by growing microorganisms with olive oil, glucose, starch, n-hexadecane, mannitol, sodium acetate, maltose, peptone, hexadecane [23, 24].

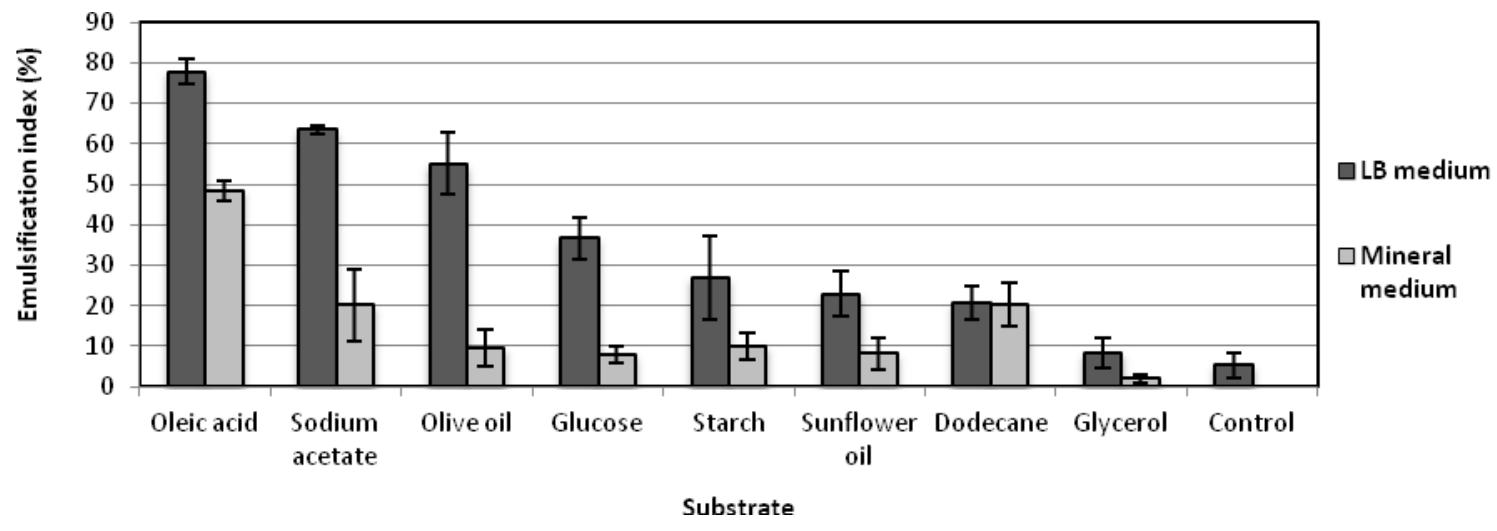

Fig. 4. An influence of carbon source on the emulsification activity

In order to research an influence the carbon source has on Arthrobacter sp. Pr82 strain, these carbon sources were picked: oleic acid, sodium acetate, olive oil, glucose, starch, dodecane and glycerol.

The maximum BE production was occurring only with oleic acid with sodium acetate and olive oil (Fig. 4) it showed better than $50 \%$ emulsification index in LB medium. The greatest emulsification activity was achieved by adding oleic acid into LB and mineral medium: EI was $77.8 \%$ and $48.4 \%$ respectively.

\section{CONCLUSION}

Three bacterial strains with a high surface active substances production capacity were screened out using hydrocarbon overlay agar method, emulsification activity determination and microscopic observation of water/fuel-oil emulsion. Arthrobacter $s p$. Pr82 showed the best results in all cases and it showed that could be used in the further studiesto designing new ecological heating technology.

Oleic acid, sodium acetate, olive oil, glucose, starch, dodecane and glycerol have been employed previously to enhance Arthrobacter sp. Pr82 bioemulsifier production. The maximum $\mathrm{BE}$ production was occurring with oleic acid and showed $77.8 \%$ EI after 1 day of cultivation.

\section{ACKNOWLEDGMENTS}

This paper reflects findings from the Economic Growth Action Programme "Intelektas LT". Project "The creation of ecological and competitive heat production technology based on the biotechnological processes (ECOFUEL)" No VP2-1.3-ŪM-02-K-03079. Contract No VP2-1.3-ŪM-02-K-03.

\section{REFERENCES}

[1] Okoliegbe I. N., Agarry O. O., 2012. Application of Microbial Surfactant (A Review). Scholarly Journals of Biotechnology. $1(1), 15-23$.

[2] Forsberg J. W., 1999. Water-in-oil emulsion fertilizer compositions. Patent No.: EP 0908434 A2.
[3] Park S., Amaral, P.F.F., Coelho, M.A.Z., Marrucho, I.M., Coutinho J.A.P. Biosurfactants from yeasts: characterististics, production and application. In: Biosurfactants. Sen, R. (ed.), Springer Science, 2010, pp. 236-249.

[4] Čipinytė V., Grigiškis S., Šapokaitė D., Baškys E. Production of biosurfactants by Arthrobacter sp. N3, a hydrocarbon degrading bacterium. Enviroment. Technology. Resources Vol. 1. 2011, pp.68.

[5] Das, K., Mukherjee, A.K. Crude petroleum-oil biodegradation efficiency of Bacilus subtilus and Pseudomonas aeruginosa strains isolated from a petroleum-oil contaminated soil from North-East India. Bioresource Technology Vol. 98, 2007, pp. 1339-1345.

[6] Perfumo A., Rancich I., Banat I.M.Possibilities and challenges for biosurfactants uses in petroleum industry. Landes Bioscience, 2008.

[7] Saharan B.S., Sahu R.K., Sharma D. A review of Biosurfactants: fermentation, Current developments and Perspectives. Genetic Engineering and Biotechnology Journal Vol. GEBJ-29. 2011.

[8] Singh A., Van Hamme J.D., Ward O. P. Surfactants in microbiology and biotechnology: Part 2. Application aspects. Biotechnology Advances. 2006, pp. 100-116.

[9] Suwansukho, P., Rukachisirikul, V., Kawai, F., H-Kittikun, A. Production and application of biosurfactant from Bacillus subtilis MUV4. Songklanakarin Journal of Science and Technology Vol. 30. 2008, pp. 87-93.

[10] Satpute S. K., Banpurkar A. G., Dhakephalkar P. K., Banat I. M., Chopade B. A., 2010. Methods for investigating biosurfactants and bioemulsifiers: a review. Critical Reviews in Biotechnology. 30(2), 127-44.

[11] Mukherjee S., Das P., Sivapathasekaran C., Sen. R., 2008. Enhanced production of biosurfactant by a marine bacterium on statistical screening of nutritional parameters. Biochemical Engineering Journal. 42, 254-260.

[12] Thavasi R., Sharma S., Jayalakshmi S., 2011. Evaluation of Screening Methods for the Isolation of Biosurfactant Producing Marine Bacteria. Journal of Petroleum \& Environmental Biotechnology. 1-6.

[13] Nishanthi R., Kumaran S., Palani P., Chellaram C., Anand T. P., Kannan V., 2010. Screening of Biosurfactants from Hydrocarbon Degrading Bacteria. Journal of Ecobiotechnology. 2/5, 47-53.

[14] Mulligan C. N., Gibbs B. F., 2004. Types, Production and Applications of Biosurfactants. Proceedings of the Indian National Science Academy. B70 (1), 31-55.

[15]Luna-Velasco M. A., Esparza-Garc1'a F., Can 1'zaresVillanueva R. O., Rodri'guez-Va'zquez R., 2007. Production and properties of a bioemulsifier synthesized by phenanthrenedegrading Penicillium sp. Process Biochemistry. 42, 310-314.

[16] Kosaric N. Biosurfactants in industry. Pure and Appl. Chem., 64(11). 1992, pp. 1731-1737. 
Žèkaitė G., Jaška V., Poška K., Andrulytė M., Grigiškis S. MICROORGANISMS PRODUCING BIOSURFACTANT SELECTION AND CHARACTERIZATION OF NEW DISCOVERED BIOEMULSIFIER THAT WILL BE USED TO CREATE ECOLOGICAL HEATING PRODUCTION TECHNOLOGY

[17] Satpute S. K., Bhawsar B. D., Dhakephalkar P. K., Chopade B. A., 2008. Assessment of different screening methods for selecting biosurfactant producing marine bacteria. Indian Journal of Marine Sciences. 37(3), 243-250.

[18] Cooper D. G., Goldenberg B. G., 1987. Surface-Active Agents from Two Bacilllus Species. Applied and Environmental Microbiology. 53(2), 224-229.

[19] Shete A.M., Wadhawa G., Banat I. M., Chopade B.A., 2006 Mapping of patents on bioemulsifier and biosurfactant: A review. Journal of Scientific and Industrial Research. 65, 91115.

[20]Desai J.D., Banat I.M., 1997. Microbial production of surfactants and their commercial potential. Microbiology and molecular biology reviews. 61(1), 47-64.
[21] Kosaric, C. N., 2001. Biosurfactants and their applications for soil bioremediation. Food Technol. Biotechnol. 39(4), 295-304. [22]Zhang X., Xu D., Zhu C., Lundaa T., Scherr K. E., 2012. Isolation and identification of biosurfactant producing and crude oil degrading Pseudomonas aeruginosa strains. Chemical Engineering Journal. 209, 138-146.

[23] Ismail W., Al-Rowaihi I. S., Al-Humam A. A., Hamza R. Y., El Nayal A. M., Bououdina M., 2012. Characterization of a lipopeptide biosurfactant produced by a crude-oil-emulsifying Bacillus sp. I-15. International Biodeterioration \& Biodegradation. 1-11.

[24] Khopade A., Ren B., Liu X.-Y., Mahadik K., Zhang L., Kokare C., 2012. Production and characterization of biosurfactant from marine Streptomyces species B3. Journal of Colloid and Interface Science. 367, 311-318. 